\title{
Reaction Patterns of Five Strains of Infectious Pancreatic Necrosis Virus in Enzyme-Linked Immunosorbent Assay
}

\author{
Masakazu HATTORI, Hiroshi KODAMA, Shinryo ISHIGURO"', Katsuji ISHIGAKI, Takeshi MIKAMI, \\ and Hisao IZAWA \\ Department of Epizootiology, Faculty of Veterinary Medicine, Hokkaido University, Sapporo 060 and ${ }^{1)}$ Central \\ Laboratories, Kyoritsu Shoji Co., Ltd., Takamihara, Kukizaki-Mura, Inashiki-Gun, Ibaraki 300-12, Japan
}

(Received 14 June 1984/Accepted 3 August 1984)

ABSTRACT. Comparison of reaction patterns among the five strains of infectious pancreatic necrosis virus
(IPNV) and an infectious bursal disease virus (IBDV) was done by using enzyme-linked immunosorbent
assay (ELISA) with antiserum against purified VR299 strain of IPNV. Five strains of IPNV were divided
into three groups by the reaction pattern: i) VR299 strain, ii) Buhl and Powder Mill strains, and iii)
d'Honnincthun and Bonnamy strains. IBDV could not be detected by ELISA using the anti-IPNV serum.
Molecular weight comparison of virion proteins revealed that size of $\beta$ proteins of IPNV was unique in
three groups of IPNV. Antigenic relationships among IPNV strains examined by immunodiffusion (ID)
showed that Buhl and Powder Mill strains were similar to VR299 strain, but d'Honnincthun and Bonnamy
strains were distinct from other three strains of IPNV. No cross reaction was observed between IBDV and
IPNV-VR299 strain by ID. These results indicate that ELISA can be used to distinguish antigenic
differences among IPNV strains and to differentiate IPNV from antigenically unrelated virus such as IBDV
which is classified in the same virus family as IPNV.-KEY wORDs: ELISA, infectious bursal disease
virus, infectious pancreatic necrosis virus, viral polypeptide.

Infectious pancreatic necrosis (IPN) is an acute, highly contagious disease mainly affecting young salmonid fish [37]. Isolation of IPN virus (IPNV) has been reported in North America [25, 38], Europe [3, 4, 33] and Japan [29]. IPNV is now characterized with bisegmented double-stranded RNA genomes and a naked, icosahedral particle $[6,8$, 23]. Many strains of IPNV have been isolated and cross neutralization test can be employed for serotyping them [13, 21, 22, 26, $28,29,34,37]$. Three major serotypes have been identified $[22,28]$. Two of these serotypes are $\mathrm{Ab}$ and $\mathrm{Sp}$ strains [35] which are found in Europe, and another serotype is VR299 strain isolated in North America [37]. A number of viruses which possess similar morphological and biochemical properties to IPNV were isolated from a variety of nonsalmonid fishes $[1,2,29,31]$ and marine invertebrates $[17,32]$. Infectious bursal disease virus (IBDV) of chickens and drosophila $\mathrm{X}$ virus (DXV) of the fruit fly are also considered to belong to the same virus family as IPNV [12]. The antigenic relationship of these IPNV-like viruses to IPNV are also not well understood.

In the previous paper, we described the double-antibody sandwich enzyme-linked immunosorbent assay (ELISA) for the detection of IPNV in tissue culture and in rainbow trout infected with the virus [14]. The sensitivity and the specificity were demonstrated by using highly purified IPNV antigen and hyperimmune serum. The present study was conducted to evaluate the antigenic relationships among 5 strains of IPNV by ELISA and by immunodiffusion (ID). The reaction patterns of ELISA were also compared with the differences in the size of viral polypeptides 
analyzed by sodium dodecylsulfate-polyacrylamide gel electrophoresis (SDS-PAGE). Further, antigenic relationships of IPNV to IBDV were examined by ELISA and ID.

\section{MATERIALS AND METHODS}

Cells: Chinook salmon embryo cell line (CHSE-214) and steelhead trout embryo cell line (STE-137) were kindly provided by Dr. T. Nagabayashi (School of Fisheries Science, University of Kitasato, Iwate, Japan). Culture media (Eagle's minimum essential medium; MEM, pH7.2) and the method for propagation of line cells are described in the previous paper [14]. Chick embryo fibroblasts (CEF) were propagated as monolayers in MEM supplemented with $10 \%$ fetal calf serum, $200 \mathrm{units} / \mathrm{ml}$ of penicillin and $200 \mu \mathrm{g} /$ $\mathrm{m} l$ of streptomycin at $37^{\circ} \mathrm{C}$.

Virus and purification of virus: IPNV strains of VR299, Buhl, Powder Mill, Bonnamy and d'Honnincthun were kindly supplied by Dr. T. Nagabayashi. Propagation of the virus in cell lines was described in the previous paper [14]. Strain of IBDV labeled RF-1 was kindly provided by Dr. M. Higashihara, Research Center for Veterinary Science, Kitasato Institute, Kashiwa, Japan. The IBDV was propagated at $37^{\circ} \mathrm{C}$ in CEF for 3 days until an extensive cytopathic effect was observed. Infected culture fluids and cells with these viruses were collected and frozen at $-20^{\circ} \mathrm{C}$ or $-80^{\circ} \mathrm{C}$ until use.

Both IPNV and IBDV were purified according to the method by Macdonald and Yamamoto [23] with a slight modification [14]. Briefly, virus materials were centrifuged for $90 \mathrm{~min}$ at $80,000 \times \mathrm{g}$ (B-60 Ultracentrifuge, Damon/IEC, Needhamhts, Mass.) and the pellet was resuspended in a small volume of TNE buffer $(0.1 \mathrm{M} \mathrm{NaCl}, 0.01 \mathrm{M}$ Tris$\mathrm{HCl}, 0.001 \mathrm{M}$ EDTA, pH7.2). The viral preparation was referred as crude IPNV. This preparation was overlayed on $\mathrm{CsCl}$ stepwise gradient solution $(3 \mathrm{~m} l$ of $40 \%(\mathrm{~W} / \mathrm{W}) \mathrm{CsCl}$, $3 \mathrm{ml}$ of $30 \% \mathrm{CsCl}$ and $1 \mathrm{ml}$ of $20 \% \mathrm{CsCl}$ ) and centrifuged at $35,000 \times \mathrm{g}$ for $16 \mathrm{hr}$ at $4^{\circ} \mathrm{C}$ using \#488 rotor. The virus band (density $1.33 \mathrm{~g} / \mathrm{cm}^{3}$ ) was harvested and suspended in a small volume of TNE buffer, and then overlayed onto $8 \mathrm{ml}$ of $20 \%$ sucrose solution in TNE buffer. Virus collected by centrifugation at $100,000 \times \mathrm{g}$ for $60 \mathrm{~min}$ was dissolved in a small volume of $0.15 \mathrm{M}$ phosphate buffered saline (PBS; pH7.2) and referred as purified IPNV.

Antisera: CHSE-214 cell line was used for the propagation of VR299 strain for preparation of antiserum. The crude IPNV (1 mg $\operatorname{protein} / \mathrm{m} l$ ) was emulsified in an equal volume of Freund's complete adjuvant and was inoculated subcutaneously into the hind foot pads of guinea pigs. A booster injection was given 3 weeks later with the same amount of the antigen and blood was taken one week after the second injection. Anti-VR299 rabbit serum was prepared by the same procedure except that purified IPNV was used and the rabbits were inoculated subcutaneouly on the back. Virus neutralization titers of these sera were 1:62,500 (anti-VR299 guinea pig serum) and 1:51,200 (anti-VR299 rabbit serum) as estimated by the method of Behrens and Kärber [18] using microplate (Falcon, Oxnard, Calif.).

Anti-IBDV chicken serum used for ID was supplied by the courtesy of Dr. M. Higashihara. The serum was collected from chickens inoculated with homogenate of bursa of Fabricius infected with RF-1 strain of IBDV. Virus neutralization titer of the serum was $1: 40,960$.

Sandwich ELISA: The method of ELISA described by Voller et al. [36] and Katze and Crowell [19] was employed with a slight modification. The detailed procedure of ELISA was described previously [14]. Polystyrene microtiter plates (Linbro, Hamden, Conn.) were coated with $0.2 \mathrm{ml}$ of $0.1 \%$ anti-VR299 guinea pig serum in $0.06 \mathrm{M}$ carbonate buffer, pH9.6. Plates were placed overnight in a humidified chamber at $4^{\circ} \mathrm{C}$ and 
were washed three times with $0.15 \mathrm{M}$ PBS, pH7.2, containing $0.05 \%$ Tween 20 (PBSTween). The plates were then recoated with $0.2 \mathrm{ml}$ of $1 \%$ gelatine in PBS and were incubated for $1 \mathrm{hr}$ at $37^{\circ} \mathrm{C}$. After three additional washes, $0.2 \mathrm{~m} l$ of serial dilutions of purified IPNV or IBDV in PBS containing $0.1 \%$ ovalbumin (Grade V, Sigma, St. Louis, Mo.) (PBS-ovalbumin) was added to the wells. After incubation for $1 \mathrm{hr}$ at $37^{\circ} \mathrm{C}$, the plates were washed and added with $0.2 \mathrm{ml}$ of $1 \%$ anti-VR299 rabbit serum in PBS-ovalbumin. The plates were incubated at $37^{\circ} \mathrm{C}$ for $1 \mathrm{hr}$ and washed. Anti-rabbit IgG goat Ig conjugated with alkaline phosphatase diluted $1: 1,500$ in PBS-Tween was added $(0.2 \mathrm{ml})$ to each well and incubated at $37^{\circ} \mathrm{C}$ for $1 \mathrm{hr}$. After washing the plates, $0.2 \mathrm{ml}$ of substrate was added to each well and incubated for $1 \mathrm{hr}$ at $37^{\circ} \mathrm{C}$. The substrate solution consisted of $2.5 \mathrm{mM} p$-nitrophenyl phosphate in $0.06 \mathrm{M}$ carbonate buffer containing $1 \mathrm{mM} \mathrm{MgCl}$. The yellow color produced by the enzymesubstrate reaction was measured in a spectrophotometer (Titertek Multiskan, Flow Lab., McLean, Virg.) at wavelength of $405 \mathrm{~nm}$. To express the antigenic relationships among five strains of IPNV, reactivity of each strain was expressed as a positive-to-negative $(\mathrm{P} / \mathrm{N})$ ratio. The ratio was calculated by the following formula:

$$
\mathrm{P} / \mathrm{N}=\frac{\text { OD of test sample }(10 \mu \mathrm{g} / \mathrm{ml})}{\begin{array}{c}
\text { OD of uninfected STE- } 137 \text { cell } \\
\text { culture fluid }(10 \mu \mathrm{g} / \mathrm{ml})
\end{array}}
$$

SDS-PAGE of viral proteins: Virion proteins were analyzed in $10 \%$ polyacrylamide slab gels, using the discontinuous SDS-gel system of Laemmli [20]. Purified IPNV was denatured with $2.5 \%$ SDS and $10 \%$ 2-mercaptoethanol for 1 to $2 \mathrm{~min}$ at $100^{\circ} \mathrm{C}$. Fifteen to $20 \mu \mathrm{g}$ of sample was loaded into the wells and electrophoresis was performed for $5 \mathrm{hr}$ at $15 \mathrm{~mA}$. After the run, the gels were stained in $0.2 \%$ Coomassie brilliant blue in $50 \%$ methanol, destained in acetic acid-methanol- water $(10: 10: 80)$. To estimate the molecular weight of viral proteins, standard kit purchased from Pharmacia (Uppsala, Sweden) was used. This is a mixture of phosphorylase $b$ $(94 \mathrm{~K})$, bovine serum albumin $(67 \mathrm{~K})$, ovalbu$\min (43 \mathrm{~K})$, carbonic anhydrase $(30 \mathrm{~K})$, soybean trypsin inhibitor $(20.1 \mathrm{~K})$, and $\alpha$-lactoglobulin (14.4K).

ID: IPNV and IBDV antigens used for ID were prepared as follows. After removal of virus particles from culture fluids by ultracentrifugation, the supernatants which contained degraded virus particles were salted out by $50 \%$ saturated ammonium sulfate. The sediment collected by centrifugation at $12,000 \times \mathrm{g}$ for $30 \mathrm{~min}$ at $4^{\circ} \mathrm{C}$ was suspended in a small volume of $0.15 \mathrm{M}$ PBS (pH7.2) and was dialized extensively against PBS. Ouchterlony plates were prepared with $1 \%$ Noble agar (Difco, Detroit, Mich.) in PBS. The plates containing antigens and antiserum were incubated at room temperature for 2 days and observed for precipitin lines.

\section{RESULTS}

Reactions of IPNV and IBDV in sandwich ELISA: The antigenic relationships in five strains of IPNV were examined by ELISA. Threefold dilutions of 5 strains of purified IPNV were added to microplate wells coated with anti-VR299 guinea pig serum. After incubation, the plate was reacted with antiVR299 rabbit serum. Figure 1 represents the response curves for five strains of IPNV and Table 1 shows $\mathrm{P} / \mathrm{N}$ ratios of these strains. These results show that homologous viral antigen (VR299 strain) gives the highest reaction in this test and other four strains of IPNV are reacted with anti-VR299 rabbit serum with the titer in the order of Buhl, Powder Mill, d'Honnincthun and Bonnamy strains.

A test was performed to determine whether IBDV could be identified by ELISA using antiserum against IPNV-VR299 strain. The results showed that IBDV could not be identified in the present system because value of 


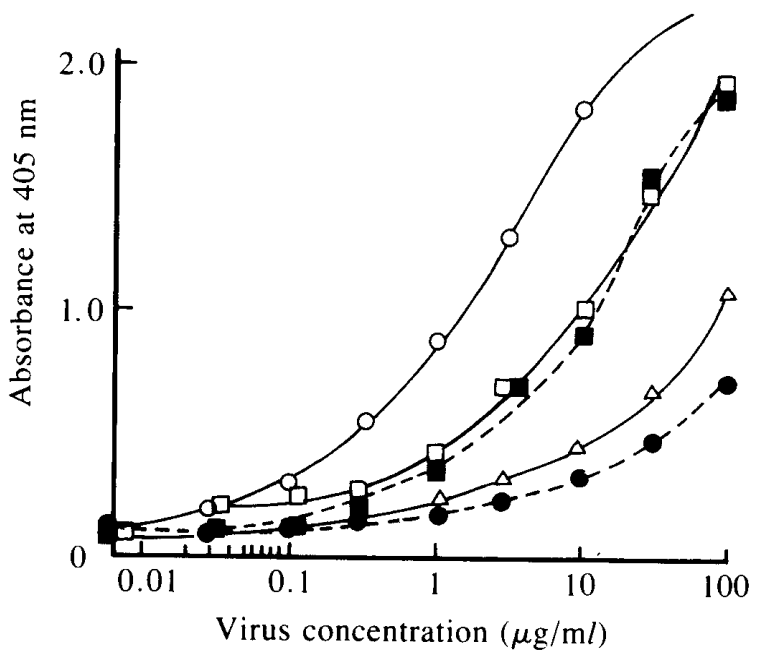

Fig. 1. Response curves of five strains of IPNV in ELISA. Each symbol represents VR299(O), Buhl(ם), Powder Mill $(\bullet)$, d'Honnincthun $(\Delta)$ and Bonnamy $(\bullet)$ strains.

\section{A $B$ C C D $\quad E$}

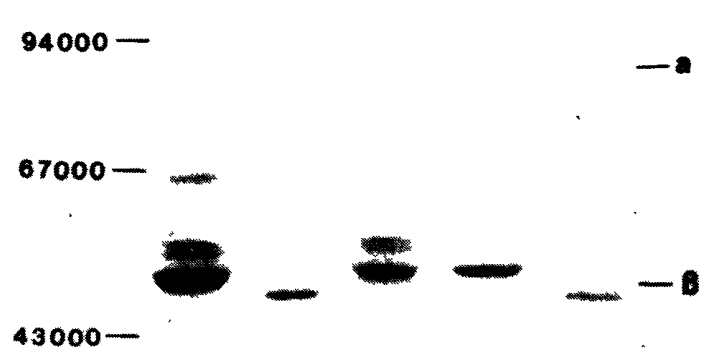

$30000-\cdots$

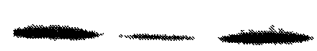

$=r$

Fig. 2. Comparison of viral polypeptides of five strains of IPNV in SDS-polyacrylamide gel electrophoresis. (A) VR299; (B) Bonnamy; (C) Buhl; (D) Powder Mill; and (E) d'Honnincthun strains. Molecular weights of marker proteins are indicated on the left side. $\alpha, \beta, \gamma_{1}$, and $\gamma_{2}$ indicate 4 viral proteins of IPNV.

absorbancy at $405 \mathrm{~nm}$ was 0.07 when $10 \mu \mathrm{g}$ of purified IBDV antigen was applied, whereas the value for purified IPNV-VR299 strain
Table 1. Identification of IPNV by the sandwich ELISA

\begin{tabular}{lcc}
\hline \multicolumn{1}{c}{ IPNV strain } & OD at $405 \mathrm{~nm}^{\mathrm{a})}$ & P/N ratio \\
\hline VR299 & 1.82 & 26.0 \\
Buhl & 1.01 & 14.4 \\
Powder Mill & 0.89 & 12.7 \\
d'Honnincthun $^{\text {b) }}$ & 0.42 & 6.0 \\
Bonnamy $_{\text {None }}{ }^{\text {) }}$ & 0.32 & 4.6 \\
\hline
\end{tabular}

a) Optical density of purified antigen $(10 \mu \mathrm{g} / \mathrm{m} l)$.

b) $\mathrm{P} / \mathrm{N}=\frac{\mathrm{OD} \text { of test sample }}{\mathrm{OD} \text { of uninfect }}$

c) Uninfected STE-137 cell culture fluid $(10 \mu \mathrm{g}$ protein $/ \mathrm{m} l$ ).

was 1.20 (data is not shown). This indicates that IBDV is antigenically distinct from IPNV.

SDS-PAGE of IPNV polypeptide: Four distinct proteins are known in IPN virions $[5,9$, $10,12]$. The result of the present study showed that $\beta$ protein was the most prominent polypeptide in all the five strains of IPNV (Fig. 2). Further, there were at least 3 polypeptides of $\beta$ size; namely 1) molecular weight (MW) 49,000 in Bonnamy and d'Honnincthun strains, 2) MW 50,000 in VR299 strain and 3) MW 52,000 in Buhl and Powder Mill strains. The experiments were repeated 3 times and the same results were obtained.

$I D$ : Antigenic relationships between five strains of IPNV were examined by using anti-VR299 rabbit serum (Fig. 3). The results indicate that antigenic characters of VR299 strain were similar to that of Buhl and Powder Mill strains but differed from Bonnamy and d'Honnincthun strains. Precipitin lines formed against Buhl strain were almost identical to that of Powder Mill strain, and the lines formed against Bonnamy and d'Honnincthun strains were similar to each other. These results were consistent with the differences in the reaction patterns of ELISA and the differences of the molecular weight of $\beta$ polypeptides of the 5 strains of IPNV.

Figure 4 shows ID patterns of IPNV-VR 


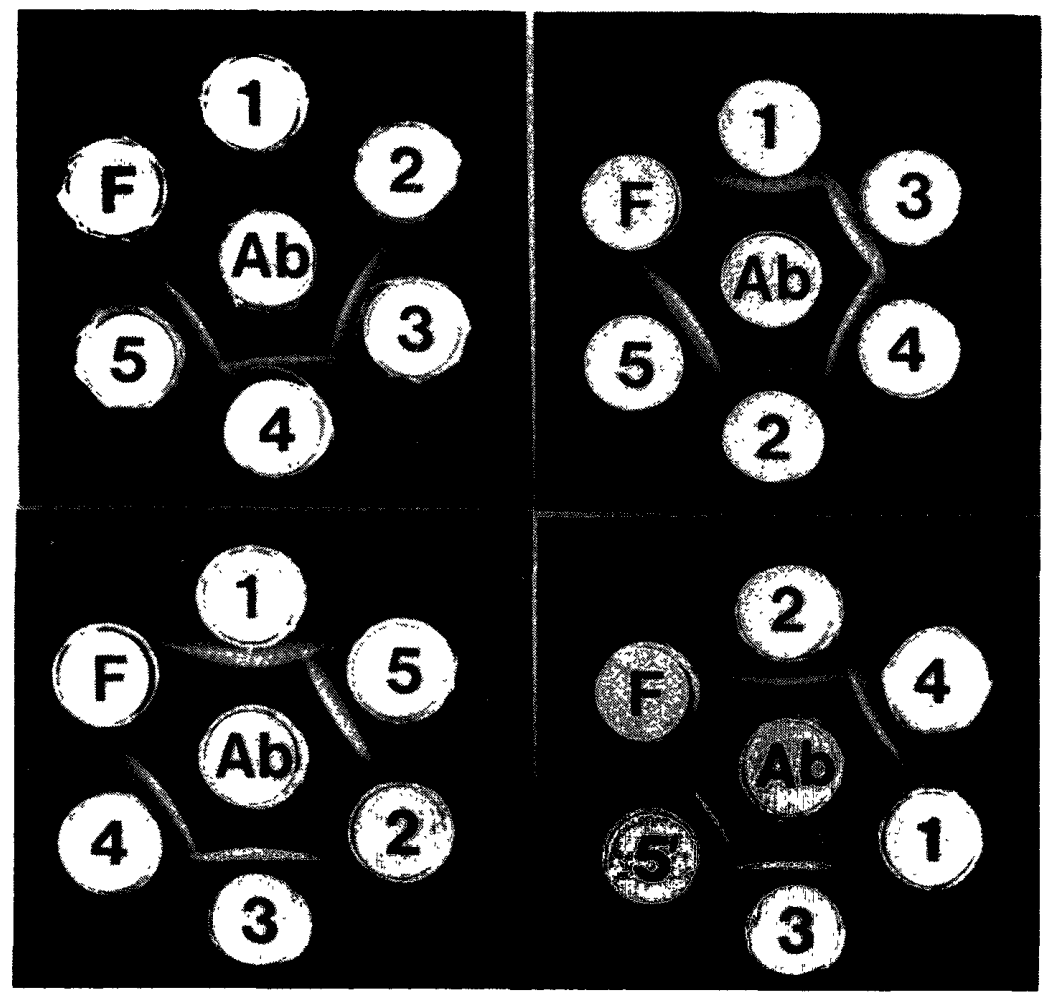

Fig. 3. Antigenic relationships of five strains of IPNV in immunodiffusion. (Ab) Anti-IPNV-VR299 strain rabbit serum; (1) VR299 strain;

(2) Bonnamy strain; (3) Buhl strain; (4) Powder Mill strain;

(5) d'Honnincthun strain; and (F) fetal calf serum.

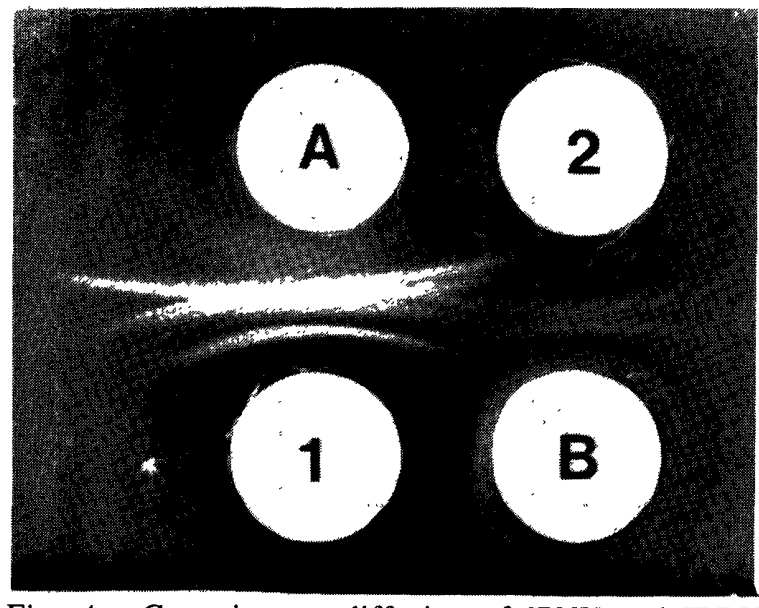

Fig. 4. Cross-immunodiffusion of IPNV and IBDV. (A) Anti-IPNV-VR299 strain rabbit serum; (B) antiIBDV-RF-1 strain chicken serum; (1) IPNV-VR299 antigen; and (2) IBDV-RF-1 antigen.

299 strain and IBDV to antiserum against homologous and heterologous virus. Precipitin lines of the two viruses were formed only against homologous but not heterologous antiserum, indicating that there was no anti- genic relationship between IPNV-VR299 strain and IBDV.

\section{DISCUSSION}

Recently, Nicholson and Caswell [27] and Dixon and Hill [7] examined the antigenic relationships of several isolates of IPNV and IPN-like viruses by ELISA using virus-infected tissue culture fluid as virus antigen and found that antiserum against one isolate of IPNV could be used to serotype IPNV strains. Katze and Crowell [19] described that the highly purified virions in ELISA were essential for type-specific identification of a group of Coxsackieviruses. Further, Herrmann et al. [16] had difficulty using partially purified virus for identification of enteroviruses in the test. Therefore, we used purified virion and its hyperimmune antiserum to compare the reactivity of 5 strains of IPNV. The results obtained in the present study indicated that the five IPNV strains were cross reacted to 
some degree and the results were essentially similar to those reported by Nicholson and Caswell [27] with one exception that the anti-VR299 serum showed the highest reaction against homologous viral antigen by our test. Further, we found that the molecular weight of $\beta$ polypeptides of five strains of IPNV could be separated into three groups. The differences in molecular weight of $\beta$ protein between these strains were consistent with the differences in the reaction patterns obtained by ELISA as described above. Macdonald and Gower [22] reported that IPNV strains were divided into 3 groups by the kinetics of their neutralization by antibody and found that molecular weight of viral polypeptide designated as VP 2 (may be equal to $\beta$ polypeptide by Dobos [9] and Dobos et al. [11]) also differed from each other when analyzed by SDS-PAGE. Since viral strains used in their study are different from those used in the present study, direct comparison of the serological relationships of selected strains can not be done. However, it seems that there is a close relationship between serological groups of IPNV and the size of viral proteins from the present and previous studies $[15,22,24]$. The molecular weight of viral polypeptides determined in the present study using $10 \%$ acrylamide gel seemed to be smaller than that reported by Dobos et al. who used $7.5 \%$ acrylamide gel [11]. This may be due to the difference in concentrations of acrylamide gel used, because we estimated that the molecular weight of $\beta$ protein of VR299 strain of IPNV was 54,000 to 56,000 when $7.5 \%$ acrylamide gel was used (unpublished). These results are consistent with the result reported by Dobos et al. [11].

When analyzed by ID in the present study, strain-specific antigen and partial common antigen were observed among 5 strains, and the reaction patterns seemed to correspond with the results of ELISA and SDS-PAGE. These results indicate that the response curves of five strains of IPNV obtained by ELISA may reflect on the biophysical and biochemical differences of viral proteins showed by the two other tests. Therefore, ELISA could be a useful method for serotyping of IPNV.

Many viruses similar or identical to IPNV have been isolated from various animal species $[1,2,17,30,31,32]$. Recently, several investigators reported the serological relationships among these isolates. Hedrick et al. [15] and Okamoto et al. [28] supposed that European eel virus was closely related to $\mathrm{Ab}$ strain of IPNV. Macdonald and Gower [22] and Underwood et al. [32] reported that oyster virus (OV) and/or Tellina virus (TV) isolated from bivalve molluscs were included in the group of IPNV. However, Dobos et al. [12] reported that IPNV was different from the other four viruses (TV, OV, IBDV and DXV) in their biophysical and biochemical natures. In the present study, we examined the antigenic relationship of IPNV and IBDV, which is one of the important pathogens of chickens, by ELISA and ID. We observed that IPNV was not antigenically related to IBDV by cross neutralization test as well as ELISA and ID (manuscript submitted to Journal).

Since the serological relationships among different strains of IPNV and the serological relatedness of the virus to IPNV-like viruses were difficult to assess by a single serological method $[21,26]$, more accurate serotyping of IPNV should be determined by using the following criteria: (i) neutralization test $[22$, 28], (ii) comparison of reaction patterns by ELISA [7, 14, 27]; and (iii) molecular weight comparison of virion proteins and RNAs [5, $12,22,32]$. In addition, monoclonal antibody may provide reagent for serotyping of these viruses.

ACKNOWLEDGEMENTS. The authors wish to express our appreciation to Dr. T. Nagabayashi and Dr. M. Higashihara for the supply of viral strains and antiserum. We thank Miss T. Ohmi for preparation of the manuscript. This work was supported by Grant-in-Aid for Co-operative Research No. 57360020 from the Ministry of Edu- 
cation, Science and Culture of Japan. Address reprint requests to Dr. Kodama.

\section{REFERENCES}

1. Adair, B. M., and Ferguson, H. W. 1981. Isolation of infectious pancreatic necrosis (IPN) virus from non-salmonid fish. J. Fish Dis. 4: 69-76.

2. Ahne, W. 1978. Isolation and characterization of infectious pancreatic necrosis virus from pike (Esox lucius). Arch. Virol. 58: 65-69.

3. Ball, H. J., Munro, A. L. S., Ellis, A., and Elson, K. G. R. 1971. Infectious pancreatic necrosis in rainbow trout in Scotland. Nature (Lond.) 234: 417.

4. Besse, P., and De Kinkelin, P. 1965. Sur l'existence en France de la necrose pancreatique de la truite arc-en ciel (Salmo gairdneri). Bull. Acad. Vet. Fr. 38: 185-190.

5. Chang, N., Macdonald, R. D., and Yamamoto, T. 1978. Morphology and polypeptide composition of ten isolates of infectious pancreatic necrosis virus. Can. J. Microbiol. 24: 19-27.

6. Cohen, J., Poinsard, A., and Scherrer, R. 1973. Physico-chemical and morphological features of infectious pancreatic necrosis virus. J. Gen. Virol. 21: 485-498.

7. Dixon, P. F., and Hill, B. J. 1983. Rapid detection of infectious pancreatic necrosis virus (IPNV) by the enzyme-linked immunosorbent assay (ELISA). J. Gen. Virol. 64: 321-330.

8. Dobos, P. 1976. Size and structure of the genome of infectious pancreatic necrosis virus. Nucleic Acid Res. 3: 1903-1924.

9. Dobos, P. 1977. Virus-specific protein synthesis in cells infected by infectious pancreatic necrosis virus. J. Virol. 21: 242-258.

10. Dobos, P., and Rowe, D. 1977. Peptide map comparison of infectious pancreatic necrosis virus specific polypeptides. J. Virol. 24: 805-820.

11. Dobos, P., Hallett, R., Kells, D. T. C., Sorensen, O., and Rowe, D. 1977. Biophysical studies of infectious pancreatic necrosis virus. J. Virol. 22: 150-159.

12. Dobos, P., Hill, B. J., Hallett, R., Kells, D. T. C., Becht, H., and Teninges, D. 1979. Biophysical and biochemical characterization of five animal viruses with bisegmented double-stranded RNA genomes. J. Virol. 32: 593-605.

13. Dorson, M., Castric, J., and Torchy, C. 1978. Infectious pancreatic necrosis virus of salmonids: Biological and antigenic features of a pathogenic strain and a non-pathogenic variant selected in RTG-2 cells. J. Fish Dis. 1: 309-320.

14. Hattori, M., Kodama, H., Ishiguro, S., Honda, A., Mikami, T., and Izawa, H. 1984. In vitro and in vivo detection of infectious pancreatic necrosis virus by enzyme-linked immunosorbent assay. Am. J. Vet. Res. 45: 1876-1879.

15. Hedrick, R. P., Okamoto, N., Sano, T., and Fryer. J. L. 1983. Biochemical characterization of eel virus European. J. Gen. Virol. 64: 14211426 .

16. Herrmann. J. E., Hendry, R. M., and Collins, M. F. 1979. Factors involved in enzyme-linked immunoassay of viruses and evaluation of the method for identification of enteroviruses. J. Clin. Microbiol. 10: 210-217.

17. Hill, B. J. 1976. Properties of a virus isolated from the bivalve mollusc Tellina tenuis (da Costa) pp. 445-452. In: Wildlife Diseases (Page, L. A. ed), Plenum Press. New York.

18. Kärber, G. 1931. Beitrag zur kollektiven Behandlung pharmakologischer Reihenversuche. Arch. Exp. Pathol. Pharmakol. 162: 480-483.

19. Katze, M. G., and Crowell, R. L. 1980. Immunological studies of the group B Coxsackieviruses by the sandwich enzyme-linked immunosorbent assay (ELISA) and immunoprecipitation. J. Gen. Virol. 50: 357-367.

20. Laemmli, U. K. 1970. Cleavage of structural proteins during the assembly of the head of bacteriophage $\mathrm{T}_{4}$. Nature (Lond.) 227: 680-685.

21. Lientz, J. G., and Springer, J. E. 1973. Neutralization tests of infectious pancreatic necrosis virus with polyvalent antiserum. J. Wildl. Dis. 9: 120 124.

22. Macdonald, R. D., and Gower, D. A. 1981. Genomic and phenotypic divergence among three serotypes of aquatic birnaviruses (infectious pancreatic necrosis virus). Virology 114: 187-195.

23. Macdonald, R. D., and Yamamoto, T. 1977. The structure of infectious pancreatic necrosis virus RNA. J. Gen. Virol. 34: 235-247.

24. Macdonald, R. D., Moore, A. R., and Souter, B. W. 1983. Three new strains of infectious pancreatic necrosis virus isolated in Canada. Can. J. Microbiol. 29: 137-141.

25. Mackelvie, R. M., and Artsob, H. 1969. Infectious pancreatic necrosis virus in young salmonids of the Canadian Maritime Provinces. J. Fish. Res. Board Can. 26: 3259-3262.

26. McMichael, J., Fryer, J. L., and Pilcher, K. S. 1975. An antigenic comparison of three strains of infectious pancreatic necrosis virus of salmonid fishes. Aquaculture 6: 203-210.

27. Nicholson, B. L., and Caswell, P. 1982. Enzymelinked immunosorbent assay for identification of infectious pancreatic necrosis virus. J. Clin. Microbiol. 16: 469-472.

28. Okamoto, N., Sano, T., Hedrick, R. P., and Fryer, J. L. 1983. Antigenic relationships of selected strains of infectious pancreatic necrosis virus and European eel virus. J. Fish Dis. 6: 
19-25.

29. Sano, T. 1971. Studies on viral disease of Japanese fishes. I. Infectious pancreatic necrosis (IPN) of rainbow trout: First isolation from epizootics in Japan. Bull. Jpn. Soc. Sci. Fish. 37: 495-498.

30. Sano, T. 1976. Viral diseases of cultured fishes in Japan. Fish Pathol. 10: 221-226.

31. Sonstegard, R. A., McDermott, L. A., and Sonstegard, K. S. 1972. Isolation of infectious pancreatic necrosis virus from white suckers (Catastomus commersoni). Nature (Lond.) 236: 174-175.

32. Underwood, B. O., Smale, C. J., Brown, F., and Hill, B. J. 1977. Relationship of virus from Tellina tenuis to infectious pancreatic necrosis virus. J. Gen. Virol. 36: 93-109.

33. Vestergard-J $\phi$ rgensen, P. E., and Bregnballe, F. 1969. Infectious pancreatic necrosis in rainbow trout (Salmo gairdneri) in Denmark. Nord. Vet. Med. 21: 142-148.
34. Vestergard-J $\phi$ rgensen, P. E., and Grauballe, P. C. 1971. Problems in the serological typing of IPN virus. Acta Vet. Scand. 12: 145-147.

35. Vestergard-J $\phi$ rgensen, P. E., and Kehlet, N. P. 1971. Infectious pancreatic necrosis (IPN) viruses in Danish rainbow trout. Nord. Vet. Med. 23: 568-575.

36. Voller, A., Bidwell, D., and Bartlett, A. 1976. Microplate enzyme immunoassays for the immunodiagnosis of virus infections. pp 500-512. In: Manual of Clinical Immunology (Rose, N. R. and Friedman, H. eds), American Society for Microbiology, Washington D. C.

37. Wolf, K., and Quimby, M. C. 1971. Salmonid viruses: Infectious pancreatic necrosis virus. Arch. Gesamte Virusforsch. 34: 144-156.

38. Wolf, K., Snieszko, S. F., Dunbar, C. E., and Pyle, E. 1960. Virus nature of infectious pancreatic necrosis in trout. Proc. Soc. Exp. Biol. Med. 104: 105-108.

要

約

酵素抗体法 (ELISA) における 5 株の伝染性膵缄壊死症ウイルスの反応性：服部雅一・坚玉 洋・石黒信良 ${ }^{1)}$.

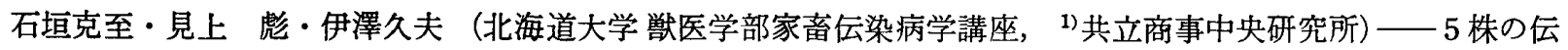
染性膵缄壊死症ウイルス (IPNV) および伝染性ファブリキウス囊病ウイルス（IBDV）1株について，酵素抗 体法 (ELISA) に怙ける反応パターンの比較を抗 IPNV-VR299 株血清を用いて行なった。 5 株の IPNVは反 応性により， i）VR299株， ii）Buhl および Powder Mill 株ならびに iii) d’Honnincthun および Bonnamy 株 の3 群に分けられ, IBDV は抗 IPNV 血清を用いた ELISA では検出されなかった。これら 3 群の IPNV 株 ビリオンにはそれぞれ分子量の等しい $\beta$ 蛋白が存在していた。これらの IPNV 株間の抗原的関連性を免疫拡散 法により調べたところ，Buhl 株执よび Powder Mill 株はVR299 株と類似していたが，これらの株とd’Honnincthun 株执よび Bonnamy 株は抗原的に異なっていた。また, IBDV と VR299 株との間には交差反応は認 められなかった。 